\title{
BRIDGING THE GAP BETWEEN REGIONAL CULTURE, CURRICULUM AND FOREIGN LANGUAGE LEARNING
}

CERRANDO LA BRECHA ENTRE CULTURA REGIONAL, CURRÍCULO Y APRENDIZAJE DE LENGUAS EXTRANJERAS

\section{Josefina Quintero Corzo'}

Universidad de Caldas, Manizales, Colombia

\section{Fabio Ignacio Munévar Quintero²}

Universidad del Magdalena, Santa Marta,

Colombia

\section{Luis Alberto Humanez Atencio ${ }^{3}$}

Universidad del Magdalena, Santa Marta, Colombia

Institución Educativa Fe y Alegría Santiago

Canabal
$1 \quad$ Full-Time Professor at Universidad de Caldas, Colombia. PhD in Education. Post-doctoral researcher. ORCID: http://orcid.org/0000-0002-9451-113X. E-mail: josefina.quintero@ucaldas.edu.co

2 Full-Time Professor at Universidad del Magdalena, Colombia. PhD in Education and Communication. ORCID: http://orcid.org/0000-0002-4263-9166. E-mail: fmunevar@unimagdalena.edu.co

3 PhD Student at Universidad del Magdalena, Colombia. Doctorado en Ciencias de la Educación -RUDECOLOMBIA. English teacher at Institución Educativa Fe y Alegría Santiago Canabal, Tierralta, Córdoba. ORCID: https:// orcid.0rg/0000-0001-5390-8125. E-mail: lahumanez@gmail. $\underline{\mathrm{com}}$

\section{ABSTRACT}

Framed within the Sociocultural theory and following the principles of the action-research approach in the classroom, this work presents final results concerning the connection between the teaching and learning of English through the incorporation of regional culture contents. To do so, a set of contextualized culturally-based 
classes were carried out in a public elementary school located in a Colombian Caribbean town. The project was developed through three stages named diagnosis, action plan, and evaluation. The results revealed that regional culture provided a contextualized environment to work in the classroom. Students acquired new and better alternatives to learn a foreign language and to recover their culture isolated from the school. It can be stated that the sociocultural approach supports theoretical and methodological principles to acquire a foreign language, enabling the students to progressively reinforce their ability to create and transfer meaningful tasks to other real situations.

KEYWORDS: Sociocultural, curriculum, foreign language, regional culture.

\section{RESUMEN}

En el enfoque de la teoría sociocultural y siguiendo los principios de la investigaciónacción en el aula, este trabajo presenta resultados finales sobre el vínculo que se establece entre la enseñanza y el aprendizaje del inglés y la incorporación de contenidos culturales regionales. Para ello, se llevó a cabo una secuencia de clases basadas en contenidos tomados del contexto cultural de una escuela pública perteneciente a un pueblo ubicado en la Región Caribe colombiana. El proyecto se desarrolló a través de tres etapas denominadas diagnóstico, plan de acción y evaluación. Los resultados indican que la cultura regional proporcionó un entorno contextualizado de trabajo en el aula. Los estudiantes adquirieron nuevas y mejores alternativas para aprender una lengua extranjera y recuperar su cultura aislada del currículo escolar. Se puede afirmar que el enfoque sociocultural apoya principios teóricos y metodológicos para la adquisición de una lengua extranjera, permitiendo a los estudiantes reforzar progresivamente su capacidad para crear y transferir tareas significativas a otras situaciones reales.
PALABRAS CLAVE: Aprendizaje, enfoque sociocultural, curriculum, lengua extranjera, cultura regional.

\section{INTRODUCTION}

Since its inception, the school has been committed to culture. Understanding the schoolcultural context relationship implies a permanent inquiring attitude to generate new visions and explanations, considering that education is a social practice that occurs in historical, geographical, cultural and ciber spacial virtual contexts. Individuals, rooted in their own culture, will be able to establish relationships between different regions in the world where language plays a fundamental role. Thus, knowing a foreign language well also means discovering and rescuing the value of other cultures in an environment of mutual peace, and respect which are necessary to ensure the progress of the humanity (United Nations Educational, Scientific and Cultural Organization -UNESCO, 2014).

Colombia is seen as a multicultural Latin American country where Spanish is the mother tongue. According to the national policies issued by the Ministry of Education (Ministerio de Educación Nacional-MEN, 2016), the acquisition of foreign languages is mandatory as a basic curricular area because it implies access to other cultures as well as dissemination of scientific knowledge. Each public school is devoted to educational service reaffirming its responsibility and identity for the development of a region. The relationship between schools, families and neighboring communities becomes a challenge that opens the possibility of thinking about a crucial topic as regional culture is.

From a theoretical point of view, the problem area identified here is supported by the most updated literature that offers varied references concerning the concept of culture, education, curriculum, and language which become inseparable components. This relationship is 
explained by the fact that the innovative or critical cultural changes have an effect on the ideals of individuals and peoples affecting the social purposes and goals.

Some authors insist that the teaching and learning process can be more meaningful if the student establishes a connection between his feelings, experiences and thoughts with the new knowledge. The theories of Ausubel (2000), Vygotski (1989) as well as Canale \& Swain (1980) are used to support the sociocultural approach in the search of better explanations to link the understanding, identity and previous daily experiences of students. Furthermore, from the perspective of emancipatory pedagogy (Freire, 2012), the student is not a depository of contents. On the contrary, the democratic school must be willing to learn from its relationships with the real context promoting active, dialogic and emancipatory methodologies that stimulate identity, participation, reflection, critical awareness and mutual understanding.

To be valid and relevant, the school curriculum must be intentionally designed within a holistic, integrated, participative and contextualized vision, based on the analysis of social reality overcoming instrumentalization (Lago, Aristizábal, Navas, Agudelo, 2014). However, Latin-American countries show a growing gap between educational goals and the daily life of the participants (Magendzo, 1996; Freire, 2012). The permanent distance between the school curriculum, pedagogical practices and the needs, interests and desires of people is confirmed.

Within the framework of the current educational reform, the mission of public educational institutions consist of looking at critical and reflective individuals as future citizens, adapted to the latest trends to face the permanent challenges focused on the third millennium. In addition, the school is oriented to the recovery of regional culture as a mean to contribute to the social development (UNESCO, 2014). It is necessary to contextualize learning experiences based on the incorporation of regional culture in such a way that they contribute to knowledge focused on their personal and social patterns in a specific environment, as well as the construction of national identity. Consequently, it is a need to appropriate an innovative proposal in schools that bridges the gap between foreign language curriculum and culture.

Rather than viewing language as a list of isolated topics, grammatical rules, linguistic structures, and unnecessary translation, language teachers have become increasingly aware that a foreign language is learned or taught successfully if it is addressed to the culture of the context in which it is spoken (Briceño, 2019). Unfortunately, there is a general dissatisfaction with the use of traditional textbooks and methodologies since most of them are based on structuralist tendencies and grammatical rules that weaken all the meanings of language and culture. The criticisms made by researchers such as Fandiño, (2013), Usma (2009) among others, insist that linguistic topics alone (that is, mechanical questions-answers) do not provide an integrative scheme of the communicative competencies.

Taking into account the concerns mentioned above, the following question is posed:

How does the sociocultural approach support the relationship between regional cuture, curriculum and the teaching-learning process of a foreign language?

In coherence, with the above question, the following objectives are:

- To integrate cultural contents taken from the regional context into the foreign language curriculum in an elementary school.

- To strengthen the relationship between the linguistic objectives, the communicative objectives, the curricular contents and the school regional culture. 
- To characterize the contributions of the sociocultural approach as a possibility of integrating the foreign language with the regional context of the student.

\section{LITERATURE REVIEW}

\section{Contemporary Concepts of Culture}

Rooted in the etymological meaning (from Latin and Greek), the words 'colere, cultus', 'colo', remain in traditional and contemporary concepts of culture. Anthropologists like Goodenough (1957) claim that culture is a way of organizing ideas as well as perceiving or interpreting the world. Geertz (2003) refers to a body of conceptions, meanings and symbols that are transmited from one generation to another. Besides, (UNESCO, 2013) asserts that "each culture is the sum of assumptions and practices shared by members of a group distinguishing them from other groups" (p. 9).

The most recent critical approaches to cultural studies (Ariño, 1997) argue that cultural practices and productions are essential elements of the social order. The territory also plays a crucial role on the material and symbolic practices created by the communities, affecting their economic, political, technological areas and even their conflicts or confrontations. When social rights are violated, norms are imposed or legitimacy is broken, the involved communities may demand legal solutions. This is the cause of protests, meetings, public hearings and calls for popular actions (Munévar, Dávila, Giraldo, 2018).

\section{The Crucial Link Between Culture, School Curriculum and Language}

The literature review offers various references that collect theoretical approaches, pedagogical principles, cognitive strategies, instruments and decisions to teach, learn, assess and evaluate the use of a foreign language in communicative situations. Contemporary trends such as pragmatic and communicative theories have to do with the relationship between culture, curriculum and languages, which are provided by structuralism and behaviorism. In general, educators participate in a permanent process related not only to knowledge but also to link languages with the broad field of culture (Briceño, 2019).

Based on the meaningful learning theory of Ausubel (2000), the cognitive structure is an organized set of images, symbols, ideas, and concepts constructed from the experiences, needs, and expectations that an individual already has acquired in a certain field of knowledge. Learning is effective, meaningful and permanent when the new content is related to existing background which must be organized in such a way that the new information can be easily linked to the cognitive structure of the learner.

The sociocultural theory of Vygotski (1989) argues that the individual assimilation process extends to the appropriation of cultural heritage. Environmental conditions and social interaction determine the origin of active learning and favor the development of higher intellectual functions. Since language is a vehicle for communication in a specific context, sociocultural elements play a crucial role in the process of shaping effective and properly organized teaching. Unlike other theories of foreirgn language teaching and learning, the sociolinguistic competence (Canale and Swain, 1980) states that language is real, natural, functional and relevant, and belongs to the cultural background of a particular community. The members of a social group are able to produce coherent sentences, both in form and meaning that are inserted in the sociocultural rules of communication between them.

According to Hymes (1972), interaction and speech are cultural practices. The connection between culture and language means that linguistic competence includes the ability of the speaker to use the language in any socio- 
cultural context attending to the social meaning. This way, the actual use of language in the natural environment goes beyond the acquisition of linguistic structures or the understanding of oral and verbal language. The communicative approach (Canale and Swain, 1980) focuses teaching on the use of authentic and functional language. Meaning is only possible in a real context because it implies a link with social experiences, needs, attitudes, motivations, actions and values. Heaton (1990) adds that the communicative approach emphasizes the meaning rather than the form and structure. The negotiation of meanings and the interaction and exchange of information between speakers enrich the system of symbols and conventions. Academic success depends on the knowledge and interaction between the participants and their immediate context.

As reported by Van Ek (1986), the sociocultural competence takes into account specific characteristics of a society and its culture, which are shown in the behavior of its members including social norms, rituals, and universal experiences. A high level of socio-cultural competence is acquired when the speaker is aware of the aspects of the culture and becomes familiar with them. The personal and collective daily experiences, values, attitudes, norms, rituals, social practices between other members are relevant keys to integrate the culture and the foreign language.

UNESCO (2014) considers that education has the mission of promoting the means and strategies for new generations to recognize and share their own cultural identity as a basis for the integration and better understanding of the existence of other cultures as a common heritage of all humanity. The Ministry of Eduction (MEN, 2000), taking into account the UNESCO recommendations, calls for enabling the conditions to participate in the global world without losing the sense of our own culture.

\section{METHOD}

The theoretical and methodological design was guided by the action research approach applied to the classroom (Kemmis and McTaggart, 1995; Kunlasomboon, Wongwanich \& Suwanmonkha, 2015), since it aims to understand a real school context and, at the same time, generate transformations concerning the needs and learning outcomes. Advances and progressive changes were obtained following three interrelated stages: diagnosis, action plan and evaluation. Data were collected through qualitative documentary analysis, interviews, class observations, transcripts, and diaries.

Considering the importance of developing foreign language classes focused on the Colombian Caribbean regional context, a public institution, located in a small town that borders the Atlantic Ocean and the Caribbean Coast in the northeastern region of the country, was selected.

Due to its geostrategic location, the Carebbean region offers a rich diversity of flora and fauna, natural landscapes, climate and other physical characteristics. The territory becomes a place of tourist attraction made up of flat areas, mountains, hills, valleys and rivers. The source of the economy is based on livestock, fishing, agriculture and plantain cultivation, among others. The typical hat made of a native-special plant is an artisan tradition that is preserved. People share celebrations, customs, beliefs, and rituals. "Vallenatos" and dances like "Cumbia" and "Mapalé" are the most famus folk music. Demographic statistics show 1,555,596 inhabitants $^{4}, 56 \%$ urban and $46 \%$ rural, $75 \%$ white and mestizo, 13\% black, mulatto and afro, $11 \%$ indigenous (Embera Katio ethnic group), and raizal and Romany (gypsies) ${ }^{5}$ less than $1 \%$.

$4 \quad$ Estadísticas, Demografía y Población. (2018). https://www.dane.gov.co

$5 \quad$ Córdoba, Colombia. >https://www.mincit.gov.co 
The research involved 33 fifth-grade participants, 21 boys and 12 girls, enrolled in a public educational institution. Their average ages were between 11 and 13 years old. They were exposed to a sequence of ten cultural-based classes for more than ten months. They were highly motivated students who wanted to acquire languages competences with the ultimate purpose of achieving the ability to interact and speak with their family and other foreigners visiting the Colombian Caribbean Region.

To collect relevant data with the purpose of detecting the relationship between content in English and the regional culture, the following instruments, techniques and procedures were included: documentary analysis such as the Institutional Educational Project (IEP), student notebooks and artifacts, recorded interviews with the Principal of the school and the English teachers, class observations, transcripts, observer journal and teacher journal.

\section{RESULTS}

\section{First Stage. Educational institution diagnosis}

The selected school is located in a strategic urban perimeter of the municipality, serving an average population of about $965^{6}$ enrolled students, 30 or 40 in each classroom. There are 390 istudents in the elementary cycle, 503 in secondary, and 72 in pre-school. The neighborhood is rated as low social stratum. Generally, the parents are farmers, peddlers, factory workers, employees, and waiters, among others.

The first stage was planned in order to consult the Institutional Education Project (IEP). According to the vision and social mission, the school is called to use knowledge to deal with the most relevant problems promoting progress through learning activities or projects whether

6 Sistema de Matrícula Estudiantil de Educación Básica y Media SIMAT de la Institución Educativa Fe y Alegría Santiago Canabal de Tierralta - Córdoba. (2020). directly or indirectly linked to the regional culture assistance. Despite limited financial support from the State and lack of resources, the school community is open to innovative changes that contribute to regional development. The Director of the school mentioned that "every year, different schools in the municipality organize an event called the Science Festival where some groups of outstanding students present innovative projects and productions". However, he affirmed that "we do not have sufficient resources to carry out more projects oriented to such objectives".

The English teachers openly expressed the importance of incorporating the regional culture into the foreign language syllabus, taking into account that it is the context where students interact day by day. Most of them recognized that "the students live in a beautiful tourist area but they are neither able to talk about its characteristics nor to understand everything about it".

The results of the diagnostic stage confirmed once more the absence of a contextualized curriculum and, therefore, the lack of practical and effective guidelines for learning a foreign language. After interviewing the foreign languages teachers, they complained about the lack of a specific textbook and authentic material on regional culture to implement in class:

Teacher 1. "The students are asked to copy from the board".

Teacher 2. "Most classes consist of transcribing and memorizing long lists of verbs, to make sentences or to answer questions without any specific cultural context".

Teacher 3. "Students seldom participate in small groups or workshops. There is no negotiation of meanings. The excessive use of Spanish and dictionaries during foreign language classes is evident. Extensive instructions and imbalance of language skills". 
The Director added: "despite the existence of highly trained teachers, almost all English classes are focused on traditional linguistic models which emphasize grammar, isolated contents, choral repetition, mechanical translation of vocabulary and structures, frequent copying of exercises from the board to the notebooks and the like".

Finally, as can be observed in the previous considerations, it was essential to implement new teaching methodologies in the classroom to improve this situation. This was the case of the soci-cultural approach.

\section{Second Stage. Action Plan}

Before starting to plan the cultural-based classes, it was necessary to go in depth in the exploration and select meaningful contents inserted in the surrounding context of the learners. The samples below are excerpts taken from the most representative cultural classes carried out.

\section{Activity 1. Countries, Nationalities and Languages}

The following fragment was taken from the transcription ${ }^{7}$ :

Teacher ( $\mathrm{T})$ : Good Morning kids!

Welcome. Hello! Sit down!

SS: Good morning teacher!

T: Okay. Who is absent today? ( $T$ takes the roll call. Few students are quiet).

T: Hello everyone. Ok let's start. (To introduce the class, the teacher located some countries on a map). We are going to describe our region. This is the activity. Let's look at the map ( $T$ points at the countries and asks the students to color the flags). Who wants to help me?

7 T: Teacher. S: Student; SS: Two or more students. S1: student 1; S2: student 2;

(): Observer's comments.
S: $\quad$ Me, teacher

T: $\quad$ Okay. What's this country?

S: $\quad$ Brazil (Bad pronunciation).

T: $\quad$ Okay, Brazil, thank you (T repeats the pronunciation). Okay, and what is the nationality of Brazil?

\section{S: $\quad$ Brazilian}

T: $\quad$ Brazilian! Thank you very much. What is the language?

SS: Portuguese

T: $\quad$ Okay, now let's go. What country is this?

S: $\quad$ Mexico

T: $\quad$ Thank you, Mexico! And what's the nationality?

S: $\quad$ Mexican

T: $\quad$ Thank you. And the language?

SS: Spanish

T: $\quad$ Thank you very much. Hey! Look at the map. Hey, what country is this?

S: Jamaica (bad pronunciation)

T: $\quad$ Don't worry, okay, repeat.

T: $\quad$ Yes, thank you, Jamaica and what's the nationality?

SS: Jamaican. And people speak English.

T: Okay, let's write it in the chart, and you complete the chart at home

T: I need two volunteers to talk about countries, nationalities and languages. Who wants to help me? 
SS: Me, teacher

T: $\quad$ Okay, welcome Luis. Who else? Welcome Antonio. !Hey, good participation!

T: Okay, Juan Pablo and Sebastian. Where does Laura live?

S: $\quad$ She lives in Haiti

T: What language does she speak?

S: $\quad$ She speaks French

$\mathrm{T}: \quad$ Hey, what country is this?

S: Colombia

T: $\quad$ Yes, O.K, kids. Did you like the class? I liked the class very much. Good participation. It was excellent. Thank you very much. Bye

\section{Activity 2. Our Caribbean Region}

T: Let's continue. Look at the map. Locate our country

T: $\quad$ Yes, this is Colombia. And what's the nationality?

SS: Colombian

T: $\quad$ And what are the colors of the flag?

SS: Yellow, blue and red (Different students at the same time).

T: $\quad$ And what language is spoken in Colombia? Anyone else? Another student, please

SS: Spanish

S: Colombia. I'm Colombian. I speak Spanish

T: $\quad$ Thank you. Okay very good.
Now let's move to activity number 2

$\mathrm{T}$ : Locate the Caribbean beach

T: Look at these pictures. How many regions are there in Colombia? Locate each region on the map. Color the Caribbean region.

T: $\quad$ O.K. Next turn. Yes, now

tell me some natural places. Lakes, mountains, rivers and streams.

S: $\quad$ The Sinú River

T: $\quad$ The Sinú River is very important in Colombia. Okay Eduard, continue. Locate the river. Mountains, lakes

S: $\quad$ Me, teacher.

T: What are the main products of the Caribbean region?

SS: Tourism

T: What are the touristic attractions in our Caribbean region?

T: Do you dance Cumbia? (Ss move simulating the dance).

A list came out: the Caribbean Sea, sunsets, rivers, family farms, churches, museums, "Corralejas" (Bullfighting Festival), craft fairs, natural landscapes, music festivals, folkloric instruments, artistic groups, the Cumbia Festival, among other folkloric annual events in the region that attract visitors from the country and abroad. Finally, the teacher asked the students to draw the most beautiful attractions in the region. They designed charts using vinyl paint, colors, modeling clay, and real material. 


\section{Activity 3. Family Farm}

According to the diary entry, students were asked to imagine an expedition around the family farm. They would bring typical materials to present a role-play displaying people, food, fruits, animals, a peasant house, and so on. At the very beginning, it was difficult for them. Sometimes, it was necessary to give extra explanations, but in the end, they played complete dialogues, questions and answers.

The following fragment is a short section taken from the transcription:

T: Yes, boys and girls... Okay. ¡Let's start! Get together in small groups. Quickly! Quickly! Follow the instructions step by step. Volunteers? Volunteers?

Ss: Teacher, that is very hard. I do not understand

T: Don't worry. I am going to help you. What does your father do?

S2: He works in a farm. He grows (sows) sugar cane

\section{S3: He works at a restaurant}

S4: My father is a chef. He prepares delicious seafood

T: What are the main agricultural products?

Ss: Coconut palm, sugar cane; plantain; "Ñame", Cassava or manioc, palm tree, coffee, fruits, pineapple...

S: My father cultivates mangoes

T: $\quad$ O.K. It is your turn Christian and July. Do you plant bananas?

S: Yes, I do.

$\mathrm{T}: \quad$ How many pigs are there in the farm? Go ahead. (Students pay attention. They seem very involved in the activity).

T: Silence, please, be quiet. How many oranges are there in the tree? (Students count, 1, 2, 3, 4, 5... etc)

S1: This is my farm: There are six cows, twenty hens

T: O.K. Thank you. Next volunteers. O.K. please, go ahead,

S2: Look at the kitchen. There is a bottle of milk on the table, some cheese and somebutter. There is a lot of rice. There is a jar of lemonade. (Student mispronouncing)

T: How much milk? Simulate that you are a plantain grower. Explain to foreign people the cultivation processes. O.K. Finish?

The children acquired specific vocabulary: chicken, turkey, cows, horses, peasants, fruits, crops, cultivation, harvest, etc. Then, they described the most common elements and tools used in a family farm. In the evaluation stage, the coordinator highlighted this activity. The observer wrote a final report in the diary: "The role play was an interactive exercise".

\section{Activity 4. Famous Restaurants in my Caribbean Region}

Talking about typical food of the Caribbean region was an interdisciplinary activity. The purpose of the class was to guide fifth-grade students to appreciate delicious food of the town, how people cook special recipes, and how foreigners consume typical dishes.

Everyone expressed their preferences, using I like..., I don't like... Then, the teacher pasted pictures on the wall. He asked the students to order step-by-step the process of coconut 
rice, salad, cakes, etc. The students repeated or imitated a series of examples given by the teacher, such as: Fish and beans Tamale is a typical food. Fish, shrimp, oysters and lobsters are sea animals.

T: Excuse me. Look at the picture on the wall. Listen to me.

T: Do you like Caribbean food? This is the menu. Seafood dishes are typical food in the Caribbean Coast

S1: Taste the Caribbean cuisine

S2: Welcome to the most famous restaurant in my town

S3: We offer healthy food: fish, chicken, rice, vegetables and fruit salad

S4: Fried fish is a nutritious food

S5: Oatmeal with milk is a nutritious drink

T: I offer you coconut shrimp with mango sauce. It is delicious!

S6: I like roast potatoes. It's very tasty as well.

S7: Serve me a lobster with pineapple sauce

S8: I offer shrimp fried in coconut oil. This recipe is very famous in the region

S9: How much is it?

T: $\$ 60$. The service is not included

SS: Thanks.

T: Do you like seafood? Do you prefer fried fish or lobster?

S: No, not at all

T: Do you like raw oysters with lemon? Oysters produce pearls (Students repeat and the teacher corrects pronunciation)
$\mathrm{T}$ : What is your favorite recipe?

$\mathrm{T}$ : Coconut shrimp is my favorite recipe. It's 3 steps process:

Step 1. Dip the shrimp into flour

Step 2. Dip the shrimp in beaten egg

Step 3. Dip it into coconut

Serve the coconut shrimp with orange marmalade.

Finally, enjoy it with salad, peanuts, and wine.

Previous concepts in Spanish were necessary to create sentences in the new language. The English teacher commented that it is a good opportunity to use the language as an instrument for incorporating cultural content. He entered the following reflection in his diary: "This cultural context helps me to sensitize my students to consume and promote regional food".

An inventory of the Caribbean cuisine was another interdisciplinary activity. In the extraschool work, students observed and described how their mothers prepared typical food of the region (for example patacón, sancocho, tamale). They also compiled recipes with the intention of practicing linguistic structures, increasing vocabulary and valuing the customs of their family heritage.

\section{Activity 5. The Illustrated Pictogram}

To obtain a complete set of data, students were asked to create tourist posters or pictograms. This activity consisted of two tasks: in the first task, students collected pictures or images based on the most famous tourist places; in the second task, they wrote a short sentence describing each image. Students were given the necessary basic grammar, linguistic structures and vocabulary to define some regional concepts 
which were used to explain to foreigners visiting the Caribbean region.

The teacher writes the basic instructions on the board. The observer continues keeping the diary entries.

T: Let's begin. You know tourists from different countries. Explain them about meals, farms, landscapes and other tourist attractions. Define some typical objects. Make a drawing or paste a photo. Invite foreigners to visit the wonderful landscapes. This was the activity that students enjoyed the most.

T: Let's check the work. (T goes through each desk checking the artifacts).

SS. This is may work, teacher.

Students were able to invent definitions, follow step-by-step instructions, locate geographic locations, explain how artisans make handicrafts or prepare typical food recipes. Most of them started working and did their best to get a good grade. Through pictures, images, drawings, and descriptions created by students, the tourists will be able to understand what "sancocho" is, what coconut rice is, what an "empanada" is, what the "sombrero vueltiao" is, and they identified those restaurants that prepare the best typical Caribbean food.

\section{Third Stage: Evaluation and Final Results}

At this point, as illustrated in the above examples, a positive attitude was displayed during the cultural-based classes. The students were satisfied and very pleased with the results. They showed willingness to each other to perform their role play. The work in small groups favored negotiation of meanings, interaction and interest. Mutual collaboration, good elicitation and command of the language was shown, although some classmates preferred direct translation. The artifacts taken from the students' notebooks and posters were the most appropriate pieces of evidence that helped the teacher to appreciate their progress and support relevant findings.

In general, in the performance of the role play the students seemed confident and fairly progressive. Although they exhibited some significant spelling, grammatical and pronunciation mistakes, there was visible advances over time in terms of new vocabulary, sentence structure, use of previous knowledge, linguistic accuracy and classroom interaction. It means that cultural contents can be used to enable students to understand and progressively reinforce their ability to apply academic tasks to other real-world situations.

Although there are still traces of translation and isolated vocabulary in the final productions (for example when they connect the typical words and verb tenses to habitual uses in Spanish). The appearance of prepositions, verbs, certain adverbs, quantity or other time expressions were difficult (for example, my father always works in the farm; my mother prepares recipes in the kitchen every day). Anyway, students were prompted to re-read their tasks and exercises out loud. They were given the turn to present their productions several times, and make any corrections that they deemed necessary.

\section{DISCUSSION}

The Socio-cultural approach provides theoretical and methodological sources that are inserted in the national bilingual policies and are supported by international theorists (Ausubel, 2000; Briceño, 2019; Van Ek, 1986; Vygotsky, 1978). They make a call to language education programs highlighting that classroom activities should take into account the link between the objectives of the school and the experiences of the students immersed in the context that surround them.

Although the contents of traditional curricular areas are totally isolated from regional 
topics (Magendzo, 1996; Freire, 2012; Lago, Aristizábal, Navas, Agudelo, 2014), even after many years of curricular reforms, new strategies can be managed within school life through culture. Based on the official syllabus (MEN, 2000; MEN, 2016), the communicative and linguistic activities provide direct access to the process of linking language and a regional culture, showing the extent to which students are able to create new meanings taken from the cultural characteristics available to them. It is a way to understand that through the sociocultural approach, students consciously recognize and construct new meanings in communicative contexts both inside and outside the classroom (Lantolf \& Beckett, 2009).

The cultural content classes implemented in this research work were based on the existing sociocultural trends that suggest: 1 ) It is possible to recover the regional cultural context and the previous experience of the students to carry out meaningful activities in class. 2) The English learning process becomes more enjoyable and authentic when the interests and needs of the students involved in their own immediate context are incorporated into the academic tasks. 3) The selection of strategies for reading, listening, speaking and writing took into account the appreciation of the regional culture of the students.

Colombian English teachers would appreciate the concept of sociocultural learning as an integrative trend in the language classroom, with the purpose of recreating and reinventing active methodologies. Contextualized activities through individual and group work favor a climate of interaction, coexistence, and negotiation of meanings (Fandiño, 2013; Heaton, 1990; Hymes, 1972). The artifacts created by the students themselves correspond to their ages, interests and abilities. This is the case of farm expeditions, role-plays, posters, and pictograms. Due to its communicative value, all these activities provided evidence to verify the extent to which the foreign language students were able to use their prior knowledge skills and understanding that describe the cultural world around them.

Students will be surely willing to compare their regional heritage with that of other regions, later on. In line with the Ministry of Education (MEN, 2000) and UNESCO (2014), the results achieved through this project ensure that the new generations take pride in rescuing the value of their own culture and personal identity and at the same time, it is possible to overcome cultural barriers.

\section{CONCLUSIONS}

As it is essential to consider the implications of learning a foreign language in the current times, the results argue in favor of using the socio-cultural approach in the communicative acquisition of a foreign language (English). New and better alternatives appear to bridge the gap between regional culture and the school curriculum, which for a long time have been isolated from each other. This is a first step to contribute, from the English classroom, to strengthening the personal and regional identity of those who, as future citizens, will appreciate the knowledge acquired in school. In this way, students reinforced and shared what they already knew about their previous experiences, explored more information, discovered what they could profit from, and shared activities with foreigners.

Students feel identified with their own heritage due to its relationship with their daily life by learning English through themes of their own region. In addition, the productions of the students (artifacts, illustrations, drawings, role-plays, realia and photos) help them to describe and share the closest cultural context and confirm a high degree of motivation and awareness about people enrolled in public educational institutions. 
Through cultural contents in the classroom, both teachers and students are sensitive and motivated because they take advantage of the complex wealth of the Caribbean region where they live. It is possible to establish better initiatives to improve the school curriculum, and more specifically, the educational fields. Students often feel motivated and proud when they understand at least an idea by themselves, and, at the same time, their classmates appreciate it. In addition, the students feel more enthusiastic when they realize that, the knowledge they have about their regional culture can be understood by others and expanded abroad.

In accordance with the principles of the sociocultural approach, English teachers would appreciate the opportunity to focus teaching on a real and useful content that the students can take advantage of in their daily life. The students can communicate in meaningful contexts using language structures and terminology on interdisciplinary topics. For this reason, this report is a sociocultural contribution oriented to educational researchers, policy makers, pre and in- service teachers, pedagogical advisors and those who want to integrate culture, curriculum and a foreign language.

\section{REFERENCES BIBLIOGRÁFICAS}

Ariño, A. (1997). Sociología de la cultura. La constitución simbólica de la sociedad. Barcelona: Ariel.

Ausubel, D. P. (2000). The Acquisition and Retention of Knowledge: A Cognitive View. Springer -Science+Business Media, B.V. The city University of New York. https://books.google.com.co/ books?

Briceño de Osorio, A. (2019). Aprendizaje de lenguas para la diversidad cultural. Episteme Koinonía. Revista Electrónica de Ciencias de la Educación,
Humanidades, Artes y Bellas Artes, 2(4), 53-71. http://dx.doi.org/10.35381/ e.k.v2i4.524

Canale, M. y Swain, M. (1980). Theoretical Bases of Communicative Approaches to Second Language Teaching and Testing. Applied Linguistics, 1(1), 1-47. https://doi.org/10.1093/applin/l.1.1

Fandiño, Y. (2013). Knowledge base and EFL teacher education programs: a Colombian perspective. Íkala, Revista de Lenguaje y Cultura, 18(1), 83-95.

Freire, P. (2012). Pedagogía de la indignación. Cartas pedagógicas en un mundo revuelto. Buenos Aires: Siglo Veintiuno Editores.

Geertz, C. (2003). La interpretación de las culturas. Barcelona: Gedisa.

Goodenough, W. H. (1957). Cultural Anthropology and Lingüístics. EnP. Garvin (Ed.), Report of the Seventh Annual Round Table Meeting on Linguistics and Language Study (pp. 167-173). Washington, D.C.: Georgetown University Press.

Heaton, J. B. (1990). Writing English Language Tests. New York: Longman.

Hymes, D. (1972). On Communicative Competence. Harmondsworth: Penguin.

Kemmis, S., McTaggart, R. y Nixon, R. (1995). The Action Research Planner. Doing Critical Participatory Action Research. Victoria: Deakin University Press.

Kunlasomboon, N., Wongwanich, S., \& Suwanmonkha, S. (2015). Research and development of classroom action research process to enhance school learning. Procedia-Social and Behavioral Sciences, $171,1315-1324$. 
Lago, D., Aristizábal, M., Navas, M. E., Agudelo, N. C. (2014). Evolución del campo del curriculum en Colombia (1970-2010). En A. Díaz-Barriga y J. M. García (Comps.), Desarrollo del curriculum en América Latina. Experiencia de diez países (pp. 105-152). Buenos Aires: Miño y Dávila Editores.

Lantolf, J., \& Beckett, T. (2009). Sociocultural theory and second language acquisition. Language Teaching, 42(4), 459-475

Magendzo, A. (1996). Curriculum. Educación para la democracia en la modernidad. Santafé de Bogotá: Antropos/Instituto para el desarrollo de la democracia Luis Carlos Galán.

Ministerio de Educación Nacional -MEN. (2000). Serie lineamientos curriculares. Idiomas extranjeros. https://www.mineducacion. gov.co/1759/w3-article-339975.html? noredirect $=1$

Ministerio de Educación Nacional -MEN. (2016). Suggested curriculum structure: Transition to 5th Grade. Retrieved from https://bit.ly/2LoPMLv

Munévar, C.A; Dávila, C., y Giraldo, R. (2018). De los conflictos socioambientales a las resistencias territoriales. Bogotá: Universidad Pedagógica Nacional; Fundación Centro Editorial e Educación y Desarrollo Humano; CINDE; Manizales Universidad de Manizales.

UNESCO [United Nations Educational, Scientific and Cultural Organization]. (2013). Intercultural competences: Conceptual and operational framework. Paris. https:// www.gvsu.edu/cms4/asset/7D7DCFF8C4AD-66A3-6344C7E690C4BFD9/ unesco-intercultural-competences-doc. pdf
UNESCO [United Nations Educational, Scientific and Cultural Organization]. (2014). Latin American and the Caribbean: Education for All 2015. Regional Review. Santiago, Chile. Retrieved from: http://unesdoc. unesco.org/images/0023/002327/232701e. pdf

Usma, J. (2009). Education and language policy in Colombia: exploring processes of inclusion, exclusion, and stratification in times of global reform. PROFILE, 11(1), 123-141.

Van Ek, J. (1986). Objectives for Foreign Language Learning. Strasbourg: Council of Europe Publishing.

Vygotski, L.S. (1989). El desarrollo de los procesos psicológicos superiores, Barcelona: Crítica. 